\title{
DIABETES AND CRITICAL LIMB ISCHEMIA: THE DEADLY DUO IN PATIENTS WITH SYMPTOMATIC PERIPHERAL ARTERY DISEASE
}

\author{
Mislav Vrsalović ${ }^{1,2}$ and Ksenija Vučur ${ }^{3}$ \\ ${ }^{1}$ School of Medicine, University of Zagreb; ${ }^{2}$ Department of Vascular Medicine, Cardiovascular Center, Sestre \\ milosrdnice University Hospital Center; ${ }^{3}$ Institute of Emergency Medicine of the Zagreb County, Zagreb, Croatia
}

\begin{abstract}
SUMMARY - Inflammation plays an important role in the initiation and progression of peripheral artery disease (PAD). Patients with diabetes have an increased risk of developing PAD. Data regarding the prognostic implication of diabetes and inflammation in PAD patients are scarce. The aim of the study was to investigate the impact of diabetes and inflammation on all-cause mortality in patients with symptomatic PAD and preserved left ventricular ejection fraction (LVEF >50\%). The study was conducted at the Sestre milosrdnice University Hospital Center between January 2010 and January 2014 on 319 consecutive patients with symptomatic PAD and preserved LVEF (66.5\% men, mean age $70 \pm 10$ years, ankle brachial index $0.58 \pm 0.14$ ). Thirty-eight (12\%) patients died during median follow up period of 24 months (interquartile range, 16-34 months). On univariate analysis, C-reactive protein was significantly associated with all-cause mortality (HR 2.21, 95\% CI 1.09-4.48). After multivariate regression analysis, age (HR 1.07, 95\% CI 1.02-1.11), diabetes (HR 2.24, 95\% CI 1.04-4.82), and critical limb ischemia (HR 2.22, 95\% CI 1.03-4.80) remained the only independent predictors for all-cause mortality. Diabetes and critical limb ischemia are independently associated with an increased risk of mortality in symptomatic PAD patients with preserved LVEF.
\end{abstract}

Key words: Diabetes mellitus; Extremities - blood supply; Ischemia; Inflammation; C-reactive protein; Mortality; Peripheral arterial disease

\section{Introduction}

Peripheral artery disease (PAD) is a multifactorial syndrome that is associated with a very high risk of ischemic events, namely myocardial infarction, stroke, and death ${ }^{1}$. The probability of having polyvascular disease is greater in patients with PAD, indicating an extensive and severe degree of systemic atherosclerosis. These patients, despite more intense medical therapy, have poorer control of modifiable risk factors and higher mortality rate ${ }^{2,3}$.

Correspondence to: Mislav Vrsalović, MD, PhD, FESC, FSVM, Department of Vascular Medicine, Cardiovascular Center, Sestre milosrdnice University Hospital Center, Vinogradska c. 29, HR10000 Zagreb, Croatia

E-mail: mislav.vrsalovic@gmail.com

Received December 23, 2015, accepted March 2, 2016
Patients with diabetes mellitus have a 2- to 4-fold higher risk of developing PAD $^{4,5}$. Progression of atherosclerosis, as well as poor outcomes, are more often present in diabetic PAD patients, probably because of the abnormal metabolic state and increase in vascular inflammation ${ }^{6}$. PAD has been identified as a risk factor for glycemic dysregulation in type 2 diabetes mellitus $^{7}$. Prospective clinical trials have shown that the occurrence of major adverse cardiovascular events (MACE) and all-cause mortality is higher in patients with both diabetes and PAD than in nondiabetic PAD patients $^{8-10}$.

C-reactive protein (CRP) has been established as a risk factor for the development of type 2 diabetes and cardiovascular disease, including $\mathrm{PAD}^{11,12}$. Elevated CRP levels are present in patients with impaired glucose tolerance and are associated with the stage of be- 
ta-cell dysfunction and insulin resistance ${ }^{13}$. Results from the West of Scotland Coronary Prevention Study have shown that CRP concentration is a significant predictor of diabetes in middle-aged men, independent of the risk factors such as body mass index, fasting triglycerides and glucose levels ${ }^{14}$. The predictive role of CRP has been well studied in acute coronary and acute aortic syndromes ${ }^{15,16}$. We have recently shown that CRP independently predicted MACE in patients with symptomatic PAD and preserved left ventricular systolic function ${ }^{17}$. Patients with $\mathrm{PAD}$ have a higher prevalence of diabetes and higher levels of inflammatory biomarkers compared to patients without $\mathrm{PAD}^{18}$.

Therefore, the aim of the study was to investigate the role of diabetes and inflammation for all-cause mortality in patients with symptomatic PAD and normal left ventricular ejection fraction (LVEF).

\section{Patients and Methods}

The study population consisted of 319 consecutive patients with symptomatic PAD and preserved LVEF admitted to the Sestre milosrdnice University Hospital Center between January 2010 and January 2014. Fiftyfive patients were excluded due to LVEF <50\% ( $n=39$ ), malignancy $(\mathrm{n}=12)$ and concomitant autoimmune disorders $(n=4)$. During hospital stay, demographic data and clinical characteristics of the patients were recorded and included general information (age, sex, weight and height), data on cardiovascular risk factors, biochemical and hematological laboratory data, comorbidities, and medications. Renal function was assessed by estimating the glomerular filtration rate (eGFR) using the Modification of Diet in Renal Disease formula ${ }^{19}$. LVEF was assessed using transthoracic echocardiography (Simpson's method), and only patients with preserved LV systolic function (LVEF >50\%) were included in the study. Baseline anemia was defined according to the World Health Organization criteria (hemoglobin level <13 g/ $\mathrm{dL}$ for men and $<12 \mathrm{~g} / \mathrm{dL}$ for women $)^{20}$.

The diagnosis of PAD was established by clinical examination, ankle brachial index (ABI) measurement, duplex sonography and/or computed tomography or magnetic resonance angiography, and confirmed with peripheral angiography using the criteria of the European Society of Cardiology and American College of Cardiology Foundation ${ }^{21,22}$. According to the Fontaine classification, among symptomatic PAD patients with preserved LVEF there were $58 \%$ of patients in stage IIB, $24 \%$ of patients in stage III and $18 \%$ of patients in stage IV. Critical limb ischemia (CLI) was defined as the presence of rest pain, ulcer or gangrene (Fontaine stages III and IV) $)^{21}$.

Diabetes was defined according to the criteria of the American Diabetes Association and was considered to be present in all patients taking antidiabetic medication ${ }^{23}$.

Hypertension was diagnosed in accordance with the European Society of Cardiology/European Society of Hypertension 2013 guidelines ${ }^{24}$.

Cardiovascular disease, in addition to confirmed PAD, was defined as history of angina, myocardial infarction, coronary revascularization (percutaneous coronary intervention or coronary artery bypass grafting), history of stroke, transient ischemic attack, or carotid revascularization.

High sensitivity CRP was determined on admission by immunoturbidimetric method (Olympus, Dublin, Ireland).

Study endpoint was the all-cause mortality. Mortality was documented by death certificates or by reviewing hospital records. The median follow up was 24 months (interquartile range 16-34 months). Outcome was assessed by independent observers blinded to patient laboratory and clinical data. The investigation was performed in accordance with the Declaration of Helsinki and was approved by the University Hospital Center Ethics Committee.

Continuous normally distributed variables were expressed as mean ( \pm standard deviation) and non-normally distributed variables as medians (interquartile range). Differences between the groups were analyzed with t-test and Mann-Whitney test for continuous variables and with $\chi^{2}$-test for categorical variables. Normality of distribution was tested with KolmogorovSmirnov test. The ability of CRP to predict mortality was tested by the receiver-operating characteristic (ROC) analysis and optimal cut-off point of CRP was dichotomized to $>$ or $<4.5 \mathrm{mg} / \mathrm{L}$. Kaplan-Meier analyses with log-rank test were performed and comparisons were based on the presence of diabetes and CLI. Cox proportional-hazards regression analysis was performed to determine the independent predictors of all-cause mortality and results were expressed as hazard ratios (HR) and 95\% confidence intervals (CI). Covariate selection included known correlates of poor cardiovascu- 
lar outcome and those that were found to be significant on univariate analysis, i.e. age, gender, CLI, anemia, renal function, $\mathrm{CRP}$ and diabetes. The value of $\mathrm{p}<0.05$ was considered statistically significant. Statistical analysis was performed using the MedCalc ${ }^{\circledR}$ Version 11.3.1.0 (MedCalc, Ostend, Belgium).

\section{Results}

Baseline characteristics of the study population are shown in Table 1. Of 319 symptomatic PAD patients with preserved LVEF, 172 (54\%) had type 2 diabetes.

Table 1. Baseline characteristics of 319 patients with symptomatic peripheral artery disease and preserved left ventricular systolic function

\begin{tabular}{|c|c|}
\hline Characteristic & \\
\hline Age (years) ${ }^{*}$ & $71(63-78)$ \\
\hline Male sex, n (\%) & $212(66.5)$ \\
\hline Ankle brachial index ${ }^{\dagger}$ & $0.58 \pm 0.14$ \\
\hline Systolic blood pressure $(\mathrm{mm} \mathrm{Hg})^{*}$ & $140(130-154)$ \\
\hline Diastolic blood pressure $(\mathrm{mm} \mathrm{Hg})^{*}$ & $80(80-90)$ \\
\hline Heart rate $(\text { beat } / \mathrm{min})^{*}$ & $75(67-80)$ \\
\hline Body mass index $\left(\mathrm{kg} / \mathrm{m}^{2}\right)^{*}$ & $27(25-30)$ \\
\hline Hypertension, n (\%) & $277(87)$ \\
\hline Diabetes mellitus, n (\%) & $172(54)$ \\
\hline Smoking, n (\%) & $173(54)$ \\
\hline Dyslipidemia, n (\%) & $242(76)$ \\
\hline Polyvascular disease, n (\%) & $132(41)$ \\
\hline Critical limb ischemia, $\mathrm{n}(\%)$ & $134(42)$ \\
\hline Anemia, n (\%) & $67(21)$ \\
\hline $\begin{array}{l}\text { High sensitivity C-reactive protein } \\
(\mathrm{mg} / \mathrm{L})^{*}\end{array}$ & $4.5(2.2-10.0)$ \\
\hline $\begin{array}{l}\text { Estimated glomerular filtration rate } \\
(\mathrm{mL} / \mathrm{min})^{\dagger}\end{array}$ & $63.4 \pm 18.3$ \\
\hline $\begin{array}{l}\text { Left ventricular ejection } \\
\text { fraction }(\%)^{\dagger}\end{array}$ & $57.0 \pm 5.5$ \\
\hline Statin therapy, n (\%) & $194(61)$ \\
\hline Antiplatelet therapy, n (\%) & $299(94)$ \\
\hline
\end{tabular}

*Median (interquartile range); $†$ mean \pm standard deviation

Fig. 1. Cumulative survival according to the presence of: (A) critical limb ischemia (CLI); (B) diabetes mellitus $(D M)$; and $(C)$ combined effect of diabetes and CLI in 319 patients with symptomatic peripheral artery disease and preserved left ventricular systolic function.
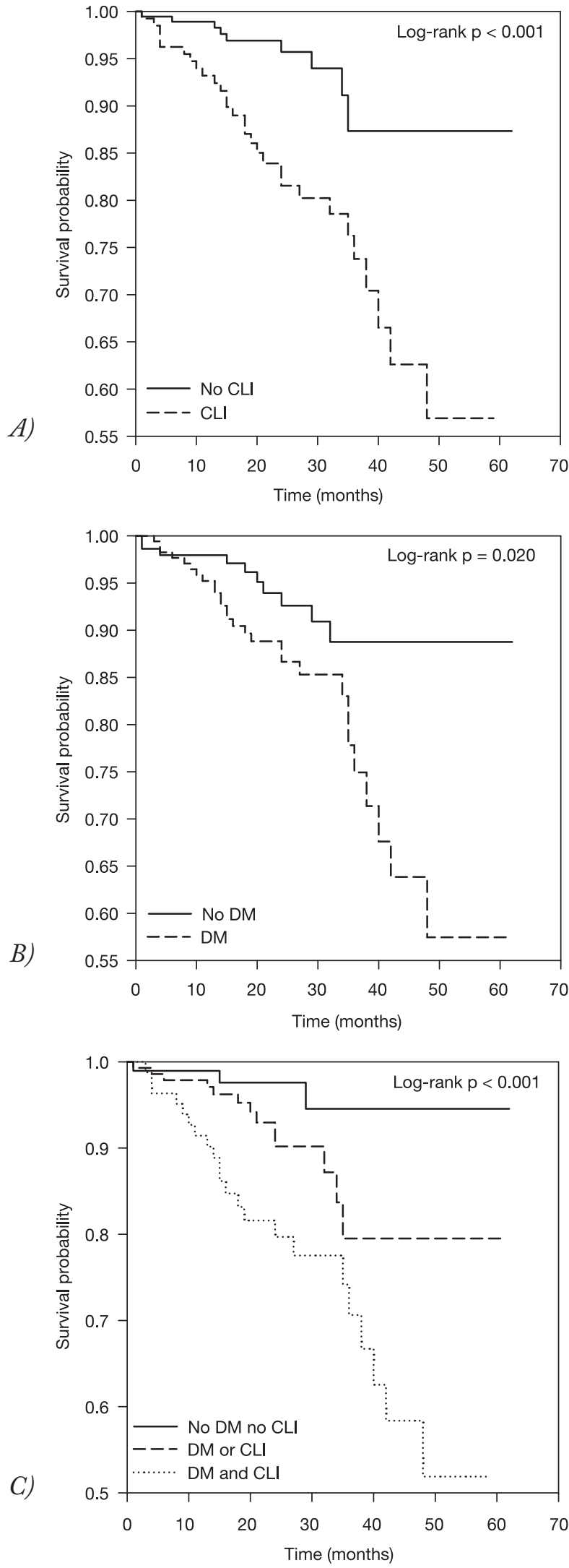
Table 2. Univariate and multivariate Cox proportional-hazards regression analysis for all-cause mortality

\begin{tabular}{|l|l|l|l|l|}
\hline \multicolumn{2}{|l|}{ Univariate } & \multicolumn{2}{l|}{ Multivariate } \\
\hline Variable & HR $(95 \% \mathrm{CI})$ & $\mathrm{p}$-value & HR (95\% CI) & p-value \\
\hline Age & $1.081(1.038-1.125)$ & $<0.001$ & $1.066(1.021-1.113)$ & 0.004 \\
Female sex & $1.404(0.738-2.671)$ & 0.304 & - & \\
Hypertension & $2.685(0.650-11.081)$ & 0.174 & - & 0.040 \\
Diabetes mellitus & $2.295(1.116-4.718)$ & 0.025 & $2.241(1.041-4.824)$ & 0.044 \\
Critical limb ischemia & $3.592(1.695-7.611)$ & $<0.001$ & $2.220(1.026-4.803)$ & \\
Polyvascular disease & $1.667(0.884-3.142)$ & 0.116 & - & \\
hsCRP $(>4.5 \mathrm{mg} / \mathrm{L})$ & $2.206(1.088-4.475)$ & 0.029 & - & \\
eGFR $(<60 \mathrm{~mL} / \mathrm{min})$ & $1.806(0.951-3.430)$ & 0.073 & - & 0.070 \\
Anemia & $3.724(1.976-7.016)$ & $<0.001$ & $1.897(0.952-3.780)$ & \\
\hline
\end{tabular}

$\mathrm{HR}$ = hazard ratio; $\mathrm{CI}=$ confidence interval; hs CRP = high sensitivity C-reactive protein; eGFR = estimated glomerular filtration rate

Among diabetics, 149 (87\%) were on oral hypoglycemic therapy or insulin, and 23 (13\%) were on diet. Thirty-eight (12\%) patients died during median follow up period of 24 months (interquartile range 16 to 34 months). On univariate analysis, age $(p<0.001)$, CLI $(p<0.001)$, diabetes $(p=0.025)$, anemia $(p<0.001)$, renal impairment $(p=0.073)$ and CRP $(p=0.029)$ were significantly associated with all-cause mortality (Table 2 ). CLI and diabetes predicted freedom from all-cause mortality, and patients having both CLI and diabetes were 6.6 times (95\% CI 2.89-14.99) more likely to die than those with claudication but without diabetes (Fig. 1A, 1B, and 1C). After multivariable analysis, age, diabetes and CLI remained the only independent predictors of mortality (Table 2).

\section{Discussion}

The present study investigated the prognostic role of diabetes and inflammation for all-cause mortality in patients with symptomatic PAD and preserved LVEF. Age, diabetes, and CLI were found to be the only independent predictors of all-cause mortality in the study population.

Previous epidemiological studies showed a higher incidence of PAD in diabetic patients. Furthermore, patients with both PAD and diabetes have more often CLI, a higher prevalence of amputation and greater risk of mortality ${ }^{25}$. Our study showed the patients with symptomatic PAD and diabetes to be at more than twofold greater risk of death compared with non-diabetic PAD patients. This is in line with Leibson et al. ${ }^{26}$, who showed that the adjusted risk of all-cause mortality in patients with both PAD and diabetes was 2.2 times higher than for patients with PAD alone. Golledge et al. ${ }^{27}$ investigated patients with occlusive or aneurysmal disease of peripheral arteries and showed 1.6- to 1.7-fold and 2.0- to 2.9-fold higher mortality risk in patients with non-medicated diabetes and patients with diabetes receiving insulin, respectively, as compared with non-diabetics.

Critical limb ischemia is the most severe form of PAD with poor overall survival. The annual mortality rate in patients with CLI is approximately $25 \%$ and between $50 \%$ and $70 \%$ at 5 years ${ }^{28}$. Lower ABI values and diabetes are the most important risk factors for the development of $\mathrm{CLI}^{29}$. Vogt et al. ${ }^{30}$ have reported that patients with $\mathrm{ABI}<0.5$ have a higher relative risk of all-cause mortality compared to patients with higher ABI values. In our study, patients with CLI had two times increased risk of all-cause mortality compared to patients without CLI.

$\mathrm{C}$-reactive protein is a regularly used biomarker in daily clinical practice, and of note, patients with diabetes have increased levels of inflammatory biomarkers, such as $\mathrm{CRP}^{8}$. Data on the prognostic role of CRP for all-cause mortality in $\mathrm{PAD}$ patients are controversial. It has been shown that in patients with symptomatic PAD, increased CRP values are independently associated with all-cause mortality within 2 years, but at longer follow up period, the biomarker lost its prognostic significance ${ }^{31}$. CRP is associated with the development and severity of PAD, as well as of impaired glucose regulation $^{12}$. Moreover, in patients with $\mathrm{PAD}$, elevated 
CRP levels correlate with the risk of cardiovascular mortality ${ }^{32}$. Recently, Mueller et al. ${ }^{33}$ have reported that CRP and CLI were independent predictors of death among patients with symptomatic PAD. Our study clearly revealed that CRP was significantly associated with all-cause mortality on the univariate but not after multivariate analysis.

Although anemia was found to be an independent predictor of composite outcome (death and limb amputation) in patients hospitalized for PAD, it was not included in the earlier outcome studies ${ }^{34}$.

We have to bear in mind that patients with chronic kidney disease have an increased risk of developing PAD, and renal impairment was found to predict all-cause mortality in patients with symptomatic $\mathrm{PAD}^{35,36}$. Left ventricular systolic dysfunction is quite prevalent in PAD patients and is associated with all-cause mortality ${ }^{37}$.

So, we believe this is the first report that showed the independent prognostic role of diabetes and CLI for mortality in symptomatic PAD patients with preserved left ventricular systolic function, regardless of renal function, anemia and inflammation.

Patients with PAD are at an increased risk of MACE and all-cause mortality compared to general population. Additionally, lower ABI values correlated with reduced survival and increased rate of concomitant coronary and cerebrovascular disease ${ }^{38}$. Despite a very high incidence of MACE and mortality rate, PAD is still underdiagnosed and undertreated. Therefore, screening for PAD, early management, together with modification of cardiovascular risk factors and timely assessment of prognosticators for unfavorable outcome are of utmost importance.

In conclusion, our data confirm that diabetes and CLI are independent predictors for all-cause mortality in patients with symptomatic PAD and preserved LVEF. Additionally, the coexistence of CLI and diabetes significantly increased the risk of worse clinical outcome.

\section{Acknowledgment}

This work was supported by grant no. 1101286 from the University of Zagreb, Zagreb, Croatia.

\section{References}

1. Gallino A, Aboyans V, Diehm C, Cosentino F, Stricker H, Falk E, et al. Non-coronary atherosclerosis. Eur Heart J. 2014; 35:1112-9, doi: 10.1093/eurheartj/ehu071
2. Suárez C, Zeymer U, Limbourg T, Baumgartner I, Cacoub P, Poldermans D, et al. Influence of polyvascular disease on cardiovascular event rates. Insights from the REACH Registry. Vasc Med. 2010;15:259-65, doi: 10.1177/1358863X10373299

3. van Kuijk JP, Flu WJ, Welten GM, Hoeks SE, Chonchol M, Vidakovic R, et al. Long-term prognosis of patients with peripheral arterial disease with or without polyvascular atherosclerotic disease. Eur Heart J. 2010;31:992-9, doi: 10.1093/ eurheartj/ehp553

4. Newman AB, Siscovick DS, Manolio TA, Polak J, Fried LP, Borhani NO, et al. Ankle-arm index as a marker of atherosclerosis in the Cardiovascular Health Study. Cardiovascular Heart Study (CHS) Collaborative Research Group. Circulation. 1993;88:837-45, doi: 10.1161/01.CIR.88.3.837

5. Murabito JM, D'Agostino RB, Silbershatz H, Wilson WF. Intermittent claudication. A risk profile from The Framingham Heart Study. Circulation. 1997;96:44-9, doi: 10.1161/01. CIR.96.1.44

6. Beckman JA, Creager MA, Libby P. Diabetes and atherosclerosis: epidemiology, pathophysiology, and management. JAMA. 2002;287:2570-81, doi: 10.1001/jama.287.19.2570

7. Blaslov K, Zibar K, Bulum T, Duvnjak L. Relationship of vascular complications and exenatide therapy failure in type 2 diabetic patients. Acta Clin Croat. 2013;52:328-36.

8. American Diabetes Association. Peripheral arterial disease in people with diabetes. Diabetes Care. 2003;26:3333-41, http:// dx.doi.org/10.2337/diacare.26.12.3333

9. Kamalesh M, Shen J. Diabetes and peripheral arterial disease in men: trends in prevalence, mortality, and effect of concomitant coronary disease. Clin Cardiol. 2009;32:442-6, doi: 10.1002/ clc. 20564

10. Jude EB, Oyibo SO, Chalmers N, Boulton AJ. Peripheral arterial disease in diabetic and nondiabetic patients: a comparison of severity and outcome. Diabetes Care. 2001;24:1433-7, http://dx.doi.org/10.2337/diacare.24.8.1433

11. Pradhan AD, Manson JE, Rifai N, Buring JE, Ridker PM. Creactive protein, interleukin 6 , and risk of developing type 2 diabetes mellitus. JAMA. 2001;286:327-34, doi: 10.1001/ jama.286.3.327.

12. Ridker PM, Cushman M, Stampfer MJ, Tracy RP, Hennekens $\mathrm{CH}$. Plasma concentration of $\mathrm{C}$-reactive protein and risk of developing peripheral vascular disease. Circulation. 1998;97: 425-8, doi: 10.1161/01.CIR.97.5.425

13. Pfützner A, Standl E, Strotmann HJ, Schulze J, Hohberg C, Lübben $\mathrm{G}$, et al. Association of high-sensitive C-reactive protein with advanced stage beta-cell dysfunction and insulin resistance in patients with type 2 diabetes mellitus. Clin Chem Lab Med. 2006;44:556-60, doi: 10.1515/CCLM.2006.108

14. Freeman DJ, Norrie J, Caslake MJ, Gaw A, Ford I, Lowe GD, et al. C-reactive protein is an independent predictor of risk for the development of diabetes in the West of Scotland Coronary Prevention Study. Diabetes. 2002;51:1596-600, http://dx.doi. org/10.2337/diabetes.51.5.1596

15. Vrsalovic M, Pintaric H, Babic Z, Pavlov M, Vrsalovic Presecki A, Getaldic B, et al. Impact of admission anemia, C-reactive 
protein and mean platelet volume on short term mortality in patients with acute ST-elevation myocardial infarction treated with primary angioplasty. Clin Biochem. 2012;45:1506-9, doi: 10.1016/j.clinbiochem.2012.05.026

16. Vrsalovic M, Zeljkovic I, Presecki AV, Pintaric H, Kruslin B. $\mathrm{C}$-reactive protein, not cardiac troponin $\mathrm{T}$, improves risk prediction in hypertensives with type A aortic dissection. Blood Press. 2015;24:212-6, doi:10.3109/08037051.2015.1025607

17. Vrsalović M, Vučur K, Car B, Krčmar T, Vrsalović Presečki A. $\mathrm{C}$-reactive protein, renal function, and cardiovascular outcome in patients with symptomatic peripheral artery disease and preserved left ventricular systolic function. Croat Med J. 2015; 56:351-6, doi: $10.3325 / \mathrm{cmj} .2015 .56 .351$

18. Marso SP, Hiatt WR. Peripheral arterial disease in patients with diabetes.J Am Coll Cardiol.2006;47:921-9, doi:10.1016/j. jacc.2005.09.065

19. Levey AS, Bosch JP, Lewis JB, Greene T, Rogers N, Roth D. A more accurate method to estimate glomerular filtration rate from serum creatinine: a new prediction equation. Modification of Diet in Renal Disease Study Group. Ann Intern Med. 1999;130:461-70, doi:10.7326/0003-4819-130-6-19990316000002

20. World Health Organization. Nutritional anemias. Report of a WHO scientific group. World Health Organ Tech Rep Ser. 1968;405:5-37.

21. European Stroke Organisation, Tendera M, Aboyans V, Bartelink ML, Baumgartner I, Clément D, et al. ESC Guidelines on the diagnosis and treatment of peripheral artery diseases: Document covering atherosclerotic disease of extracranial carotid and vertebral, mesenteric, renal, upper and lower extremity arteries: the Task Force on the Diagnosis and Treatment of Peripheral Artery Diseases of the European Society of Cardiology (ESC). Eur Heart J. 2011;32:2851-906, doi:10.1093/eurheartj/ehr211

22. Rooke TW, Hirsch AT, Misra S, Sidawy AN, Beckman JA, Findeiss LK, et al. 2011 ACCF/AHA focused update of the guideline for the management of patients with peripheral artery disease (updating the 2005 guideline): a report of the American College of Cardiology Foundation/American Heart Association Task Force on Practice Guidelines: developed in collaboration with the Society for Cardiovascular Angiography and Interventions, Society of Interventional Radiology, Society for Vascular Medicine, and Society for Vascular Surgery. Catheter Cardiovasc Interv. 2012;79:501-31, doi: 10.1161/CIR. 0b013e31822e80c3

23. American Diabetes Association. Standards of medical care in diabetes 2015. Diabetes Care. 2015;38 Supp1 1:S1-93.

24. Mancia G, Fagard R, Narkiewicz K, Redon J, Zanchetti A, Böhm M, et al. 2013 ESH/ESC Practice Guidelines for the Management of Arterial Hypertension. Blood Press. 2014; 23:3-16, doi: 10.3109/08037051.2014.868629

25. Thiruvoipati T, Kielhorn CE, Armstrong EJ. Peripheral artery disease in patients with diabetes: epidemiology, mechanisms, and outcomes. World J Diabetes. 2015;6:961-9, doi: 10.4239/ wjd.v6.i7.961.
26. Leibson CL, Ransom JE, Olson W, Zimmerman BR, O'Fallon WM, Palumbo PJ. Peripheral arterial disease, diabetes, and mortality. Diabetes Care. 2004;27:2843-9, http://dx.doi.org/ 10.2337/diacare.27.12.2843

27. Golledge J, Quigley F, Velu R, Walker PJ, Moxon JV. Association of impaired fasting glucose, diabetes and their management with the presentation and outcome of peripheral artery disease: a cohort study. Cardiovasc Diabetol. 2014;13:147, doi: 10.1186/s12933-014-0147-2.

28. Dormandy J, Heeck L, Vig S. The fate of patients with critical leg ischemia. Semin Vasc Surg. 1999;12:142-7.

29. Aquino R, Johnnides C, Makaroun M, Whittle JC, Muluk VS, Kelley ME, et al. Natural history of claudication: long-term serial follow-up study of 1244 claudicants. J Vasc Surg. 2001; 34:962-70, http://dx.doi.org/10.1067/mva.2001.119749

30. Vogt MT, McKenna M, Anderson SJ, Wolfson SK, Kuller LH. The relationship between ankle-arm index and mortality in older men and women.J Am Geriatr Soc. 1993;41:523-30, doi: 10.1111/j.1532-5415.1993.tb01889

31. Criqui MH, Ho LA, Denenberg JO, Ridker PM, Wassel CL, McDermott MM. Biomarkers in peripheral arterial disease patients and near- and longer-term mortality. J Vasc Surg. 2010; 52:85-90, doi: 10.1016/j.jvs.2010.02.004

32. Vidula H, Tian L, Liu K, Criqui MH, Ferrucci L, Pearce WH, et al. Biomarkers of inflammation and thrombosis as predictors of near-term mortality in patients with peripheral arterial disease: a cohort study. Ann Intern Med. 2008;148:85-93, doi:10.7326/0003-4819-148-2-200801150-00003

33. Mueller T, Hinterreiter F, Luft C, Poelz W, Haltmayer M, Dieplinger B. Mortality rates and mortality predictors in $\mathrm{pa}^{-}$ tients with symptomatic peripheral artery disease stratified according to age and diabetes. J Vasc Surg. 2014;59:1291-9, doi: 10.1016/j.jvs.2013.11.063

34. Desormais I, Aboyans V, Bura A, Constans J, Cambou JP, Messas E, et al. Anemia, an independent predictive factor for amputation and mortality in patients hospitalized for peripheral artery disease. Eur J Vasc Endovasc Surg. 2014;48:202-7, doi: 10.1016/j.ejvs.2014.04.005

35. Sefer S, Trotić R, Degoricija V, Vrsalović M, Ratković-Gusić I, Kes P. Healing of skin necrosis and regression of anticardiolipin antibodies achieved by parathyroidectomy in a dialyzed woman with calcific uremic arteriolopathy. Croat Med J. 2001;42:679-82.

36. Mlekusch W, Exner M, Sabeti S, Amighi J, Schlager O, Wagner $\mathrm{O}$, et al. Serum creatinine predicts mortality in patients with peripheral artery disease: influence of diabetes and hypertension. Atherosclerosis. 2004;175:361-7, http://dx.doi.org/ 10.1016/j.atherosclerosis.2004.04.008

37. Hedberg P, Hammar C, Selmeryd J, Viklund J, Leppert J, Hellberg A, et al. Left ventricular systolic dysfunction in outpatients with peripheral atherosclerotic vascular disease: prevalence and association with location of arterial disease. Eur J Heart Fail. 2014;16:625-32, doi: 10.1002/ejhf.95

38. Khan TH, Farooqui FA, Niazi K. Critical review of the ankle brachial index. Curr Cardiol Rev. 2008;4:101-6, doi: 10.2174/ 157340308784245810. 


\section{Sažetak \\ ŠEĆERNA BOLEST I KRITIČNA ISHEMIJA EKSTREMITETA: SMRTONOSNI DVOJAC U BOLESNIKA SA SIMPTOMATSKOM PERIFERNOM ARTERIJSKOM BOLEŠĆU}

\section{Vrsalovići i K. Vučur}

Upala igra važnu ulogu u nastanku i napredovanju periferne arterijske bolesti (PAB). Bolesnici sa šećernom bolešću imaju povišen rizik za razvoj PAB. Podatci o utjecaju šećerne bolesti i upale na prognozu PAB su oskudni. Cilj studije bio je istražiti utjecaj šećerne bolesti i upale na ukupnu smrtnost u bolesnika sa simptomatskom PAB i očuvanom sistoličkom funkcijom lijeve klijetke (istisna frakcija lijeve klijetke >50\%). Studija je provedena u razdoblju od siječnja 2010. do siječnja 2014. godine na 319 bolesnika sa simptomatskom PAB i očuvanom sistoličkom funkcijom lijeve klijetke (66,5\% muškaraca, prosječna dob $70 \pm 10$ godina, pedobrahijalni indeks $0,58 \pm 0,14$ ). Tijekom razdoblja praćenja od 24 mjeseca (interkvartilni raspon 16-34 mjeseca) 38 (12\%) bolesnika je umrlo. C-reaktivni protein bio je statistički značajno povezan s ukupnom smrtnošću u univarijatnoj analizi (HR 2,21; 95\% CI 1,09-4,48). Nakon multivarijatne regresijske analize, dob (HR 1,07; 95\% CI 1,021,11), šećerna bolest (HR 2,24; 95\% CI 1,04-4,82) i kritična ishemija ekstremiteta (HR 2,22; 95\% CI 1,03-4,80) bile su jedini značajni nezavisni predskazatelji ukupne smrtnosti. Šećerna bolest i kritična ishemija ekstremiteta nezavisno su povezani s povišenim rizikom smrtnosti u bolesnika sa simptomatskom $\mathrm{PAB}$ i očuvanom sistoličkom funkcijom lijeve klijetke.

Ključne riječi: Dijabetes melitus; Ekstremiteti - prokrvljenost; Ishemija; Upala; C-reaktioni protein; Smrtnost; Periferna arterijska bolest 